\title{
KILKA UWAG O WPLYWIE HEZYCHAZMU NA PRZEDSTAWIENIE CHRZTU CHRYSTUSA NA PRZYKLADZIE SZTUKI Z TERENÓW KRÓLESTWA SERBII
}

Wpływ hezychazmu na przedstawienie chrztu Chrystusa nie jest tak oczywisty, jak ma to miejsce w przypadku scen Przemienienia, Anastasis czy Koimesis. Nie doczekał się jednakże własnego opracowania w przeciwieństwie do wyżej wymienionych.

Na terenach Królestwa Serbii scena chrztu Chrystusa w Jordanie jest ilustrowana według pewnego schematu. Środkową część przedstawienia zajmuje rzeka Jordan, której oba brzegi są górzyste. W nurcie rzeki stoi Chrystus. Jest on ukazany bądź frontalnie, bądź w lekkim kontrapoście, w perizonium lub nagi. Po lewej stronie przedstawienia, na brzegu rzeki, w pozie bardziej lub mniej pochylonej, stoi, bosy lub w sandałach, Jan Chrzciciel. Prawą rękę trzyma na głowie Chrystusa. Ubrany jest w melotę i przepasany himationem. Na przeciwległym brzegu, w pozie lekko pochylonej stoi grupa aniołów (od dwóch do sześciu). Odziani są w szaty antyczne. W wodach Jordanu bywają przedstawiane personifikacje Rzeki oraz Morza. Ponad głową Chrystusa zaznaczona jest strefa niebiańska, a na promieniu światła skierowanym ku głowie Chrystusa widnieje gołębica, symbol Ducha Świętego.

Gołębica (il. 1-4) jest otoczona mandorlą. Czasami ze względu na stopień zniszczenia malowidła nie jesteśmy w stanie odpowiedzieć, czy taka mandorla istnieje. Przedstawienie chrztu należy do nielicznych wizerunków, na których ukazana została cała Trójca Święta. Jednym z najwcześniejszych przedstawień z mandorlą otaczająca gołębicę jest scena chrztu znajdująca się w Prizreniu (il. 1), w kościele fundowanym przez króla Milutina (1253 - 29 X 1321) i dekorowanym przez dwóch braci: Michała Astrapasa (floruit: 1294-1317) i Eutychiosa (floruit: 1294-1317). Duch Święty znajduje się na tle okragłej, podwójnej mandorli z dodatkowymi sześcioma promieniami światła. U góry przedstawienia umieszczono wrota niebios, z których wyłania się Manus Dei. Dla porównania, w dekoracji kościoła w Staro Nagoričane (ten sam fundator i autorzy dekoracji) (il. 2), scena chrztu zlokalizowana została nie w dodekato-

\footnotetext{
* Mgr Agnieszka Piórecka - doktorantka w Instytucie Historii Sztuki Uniwersytetu Jagiellońskiego w Krakowie; e-mail: aga@aga.priv.pl.
} 
rtonie, lecz w cyklu menologionu, a gołębica umieszczona została nie tyle na mandorli, a na promieniach światła rozchodzących się symetrycznie w czterech kierunkach. Podobny zabieg z promieniami światła artyści wykorzystali w dekoracji kościoła w Ččer (il. 3), choć w tym przypadku jest widoczna niewielka, okragła mandorla, a promienie światła są ukształtowane bardziej dekoracyjnie. Niebo zaznaczone zostało łukiem oraz dodatkowymi promieniami światła. Z nieba zaś wyłania się Manus Dei. O ile okres panowania króla Milutina i dekoracja malarska z nim związana nie jest jednolita ikonograficznie (nie zawsze gołębica jest umieszczona w mandorli), to w następnych latach elementy mistycznego światła na stałe trafiają do ikonografii. Tak będzie w przypadku monasteru patriarchalnego w Peci i kościoła św. Demetriusz (il. 4). Malowidło to powstało prawdopodobnie w latach 1322-1324 ${ }^{1}$. Duch Święty został umieszczony na tle wyraźnej okraggłej mandorli z dodatkowymi sześcioma promieniami światła, a Niebo zostało tym razem zaznaczone wyraźnie jaśniejszym łukiem. Interesująco przedstawia się również mandorla $\mathrm{z}$ dekoracji kościoła w Dečanach (il. 5). Nosi ona nietypowy romboidalny kształt, niespotykany $\mathrm{w}$ innych przedstawieniach, $\mathrm{z}$ czterema dodatkowymi promieniami światła. Ponad głową Chrystusa, tak jak i w przypadku przedstawienia w Prizreniu, Manus Dei wyłania się z otwartych drzwi. Dla podkreślenia roli światła całość nieba (zarówno łuk jak i wrota) jest w kolorze białym.

W XIV w., jak wiadomo, w kościele ortodoksyjnym trwała dyskusja dotycząca m.in. form monastycznego życia duchowego. Miała ona przede wszystkim charakter teologiczny i dotyczyła hezychastycznej metody modlitwy, rozpatrywanej w świetle wcześniejszej tradycji, odnoszącej się do poznania Boga, chrystologii i antropologii. Początek rzeczonej debacie dała konfrontacja, do której doszło pomiędzy Grzegorzem Palamasem (1296 - 14 XI 1359), mnichem pochodzącym z Góry Atos, a Barlaamem (ok. 1290 - 1 VII 1348), italo-greckim filozofem z Kalabrii. Grzegorz Palamas przekonywał, że bezpośrednie poznanie Boga w Chrystusie dostępne jest dla każdego ochrzczonego. Jest ono zatem realną podstawą i kryterium prawdziwej teologii. Barlaam z kolei podkreślał bezpośrednią niepoznawalność Boga. Jego zdaniem człowiek może poznać Go tylko pośrednio, poprzez lekturę Biblii, czyli księgi natchnionej, wnioskowanie na podstawie dzieła stworzenia, czy też (wyjątkowo) drogą objawienia mistycznego. Dyskusja ta nie obiegała więc zasadniczo od debat prowadzonych pomiędzy Symeonem Nowym Teologiem (949 - 12 III 1022), a niektórymi z jego mnichów. Ci ostatni negowali bowiem możliwość bezpośredniej wizji Boga. Barlaam skrytykował również metodę modlitwy praktykowaną przez hezychastów, określając ją jako formę mesaliańskiego

${ }^{1}$ Fundatorem dekoracji malarskiej w kościele pod wezwaniem św. Demetriusza był albo arcybiskup Nikodem ( $†$ 1325), i wówczas jest ona datowana na lata 1322-1324, albo ich fundatorem był arcybiskup Joannicjusz II († 3 IX 1354), a w tej sytuacji dekoracja ta będzie datowana na lata 1337-1357. 
materializmu². Była to w gruncie rzeczy krytyka starej, choć w dużej mierze nieformalnej tradycji teologicznej. Należy jednakże podkreślić, że doktryna ta była uznawana przez ówczesne autorytety jako całkowicie zgodna z najdawniejszą tradycją chrześcijańską̧. Ostatecznie, jak wiadomo, Kościół bizantyński uznał argumenty Grzegorza Palamasa, a tym samym zaakceptował teologię hezychastów.

Chociaż niektórzy badacze uważają tę metodę modlitwy za powrót do początków monastycyzmu, to John Meyendorff (17 II 1926 - 22 VII 1992) zauważał, że praktycznie pojawiła się ona w dokumentach pisanych dopiero w końcu XIII lub na początku XIV w. Opisuje ją anonimowy autor w Metodzie świętej modlitwy i uwagach. Autorstwo tego utworu niektóre rękopisy przypisują Symeonowi Nowemu Teologowi lub Grzegorzowi Synaicie (1255/1265 27 XI 1346), którzy byli powszechnie znani w krajach słowiańskich. Nie ulega wattpliwości, że ta metoda modlitwy była szeroko znana, a Grzegorz Palamas jako jej adeptów przytacza patriarchę Atanazego I (ok. 1230 - 28 X 1310) oraz metropolitę Filadelfii, Teoleptusa (ok. 1250 - ok. 1325) ${ }^{4}$.

Wieki XIII i XIV to okres zmian zarówno stylistycznych jak i ikonograficznych w sztuce bizantyńskiej, chociaż badacze nie są zgodni co do przyczyn tego zjawiska. Niestety z tego okresu nie posiadamy żadnych źródeł pisanych, które zawierałyby dowody na związek pomiędzy nowymi trendami artystycznymi a mistycznymi. Niemniej jednak bezsporny jest udział dwóch XIV-wiecznych ruchów duchowego i teologicznego, chodzi mianowicie o hezychazm oraz humanizm, w rozwoju artystycznym tzw. renesansu Paleologów. W tym czasie świat bizantyński ponownie sięgał do swoich greckich korzeni w kulturze, edukacji i filozofii. Zwolennicy humanizmu interpretowali prawdy dogmatyczne za pomoca sceptycznego rozumu. Jako podstawowe kryterium myśli chrześcijańskiej przyjmowali filozofię neoplatońską i Arystotelesa (384-322 prz. Chr.). W tym czasie nastąpiło też zwiększenie liczby edycji klasycznych dzieł literackich oraz odnoszących się do nich komentarzy. Powstawały także humanistyczne traktaty o charakterze świeckim. Również retoryka wykazała w tym okresie przypływ sił witalnych. Wszystko to sprzyjało rozkwitowi kultury i sztuki ${ }^{5}$. Możemy zatem wyróżnić dwa trendy w sztuce okresu panowania Paleologów. Jeden, związany jest z obfitością idei humanistycznych. Z tym związana była także tendencja do przejmowania klasycznych cech artystycznych, wzbogacania symboliki obrazów, pojawiania się elementów świeckich w dziełach religijnych oraz pewne ślady podejścia

\footnotetext{
${ }^{2}$ Por. J. Meyendorff, Teologia bizantyjska: historia i doktryna, tłum. J. Prokopiuk, Warszawa 1984, 98-99.

${ }^{3}$ Por. I. Trzcińska, Światło i obłok. Z badań nad bizantyńska ikonografia Przemienienia, Kraków 1998, 9.

${ }^{4}$ Por. Meyendorff, Teologia bizantyjska, historia i doktryna, s. 99.

${ }^{5}$ Por. A. Strezova, Hesychasm and Art: The Appearance of New Iconographic Trends in Byzantine and Slavic Lands in the $14^{\text {th }}$ and $15^{\text {th }}$ Centuries, Canberra 2014, 1.
} 
emocjonalnego ${ }^{6}$. Drugi trend, związany jest z wpływem hezychazmu na sztukę religijną zarówno na terenie Cesarstwa Wschodniego, jak i na ziemiach słowiańskich. Zaznaczyć przy tym trzeba, że to drugie zagadnienie jest znacznie gorzej opracowane naukowo ${ }^{7}$. W sztuce tego okresu często ukazane są wydarzenia historyczne, takie jak zwycięstwo hezychazmu reprezentowane przez ikonę „Niedzieli Ortodoksji”. Przedstawiani byli tam m.in. główni protagoniści ruchu hezychastycznego, jak Grzegorz Palamas czy Jan Kantakuzen (1294/1295 - 15 VI 1383). Pod wpływem ascetycznej tradycji w miejsce scen świętych wojowników zaczęły pojawiać się sceny narracyjne z życia pustelników. Mistyczna duchowość hezychazmu rozprzestrzeniła się również poza granice Cesarstwa i wpłynęła na rozwój nowych tendencji artystycznych na ziemiach słowiańskich. Sztuka takich mistrzów jak Teofanes Grek (ok. 1340 - ok. 1410) czy Manuel Eugenikos (XIV w.) była do głębi przepojona myślą hezychastyczną. Pojawiły się bezcielesne, wyidealizowane postacie ożywione religijnym liryzmem oraz wzniosłą duchowością. Tendencję tę możemy zaobserwować m.in. w kościołach południowej Macedonii, na wyspach Morza Egejskiego, a także w klasztorach Serbii, Bułgarii i Rumunii. W XIV i XV w. daje się również zauważyć wzrost liczby kościołów pod wezwaniem Przemienienia Pańskiego ${ }^{8}$. Wszystko to świadczy o wpływie hezychazmu na sztukę ziem słowiańskich ${ }^{9}$. Rozważając drogi którymi idea hezychazmu podążała na ziemie słowiańskie, nie możemy naturalnie zapomnieć o jego najważniejszym źródle, a mianowicie o klasztorach na Górze Atos, w których jego zwolennicy, tacy jak Grzegorz Synaita, Filoteusz Kokkin (ok. 1300 - 1379), Kalikst I († 1363) czy św. Sawa (1175/1176 - ok. 1235) spędzali wiele lat, praktykując tę właśnie formę życia duchowego. Wielu uczonych zgadza się z tezą że hezychazm był elementem powszechnej słowiańskiej odnowy, jednak przedstawienie i wyjaśnienie głębszych związków pomiędzy nim a owym słowiańskim „renesansem” duchowym pozostaje jak na razie „białą plamą”. Hezychazm stał się też w pewien sposób elementem wspólnej tradycji kulturowej Greków i Słowian. Odegrał on także rolę swego rodzaju pośrednika pomiędzy tymi dwoma kręgami kulturowymi, podobną do tej jaką spełnił ruch cyrylo-metodiański pomiędzy IX a XI wiekiem ${ }^{10}$. Rozwój kulturowy i intelektualny Serbii zbiegł się wręcz w czasie z rozprzestrzenianiem się na jej terytorium ruchu hezychastycznego. Ten zaś miał ścisły związek z serbskim klasztorem na Górze Atos - Chilandar. Już św. Sawa przeniósł praktykę hezychazmu na teren królestwa. Jego typikon, stworzony dla klasztoru Chilandar, stanowił swoistą definicję hezychastycznego życia monastycznego. W okresie panowania cara Duszana (ok. 1308 - 20 XII 1355), dzięki „hellenizacji” Serbii wzrósł wpływ

\footnotetext{
${ }^{6}$ Por. tamże, s. 2.

${ }^{7}$ Por. tamże, s. 3.

${ }^{8}$ Por. tamże, s. 4.

${ }^{9}$ Por. tamże, s. 5.

${ }^{10}$ Por. tamże, s. 26-27.
} 
hezychazmu. To właśnie na terenie Serbii po raz pierwszy przełożono dzieła Palamasa na język słowiański. Z kolei za panowania księcia Łazarza Hrebelianovićia (1329 - 15 VI 1389) do Serbii dotarło wielu mnichów, pisarzy i artystów. Szukali tam oni schronienia przed nieustannymi wojnami toczonymi na terenie Cesarstwa. W ostatniej ćwierci XIV w., w Górach Kučaj we wschodniej części kraju powstała nowa kolonia hezychastów, tzw. Mnichów Synaitów, o serbskim, bułgarskim i greckim pochodzeniu. Jeden z mnichów, Romil z Widynia (ok. 1327 - ok. 1375), który miał mieszane, grecko-słowiańskie pochodzenie dołączył do exodusu mnichów, którzy uciekali przed tureckimi atakami wymierzonymi w Górę Atos, i przeniósł się na wybrzeże albańskie, aby ostatecznie osiąść w klasztorze w Rawanicy, gdzie zmarł. Był on faktycznym sprawcą transplantacji hezychazmu na teren serbskich monasterów. Niektórzy badacze uważają, że tzw. morawska szkoła malarska, była twórczym przykładem sztuki inspirowanej hezychazmem ${ }^{11}$.

Wschodni mistycy często mówili o świetle, jako o swego rodzaju oglądzie Boga. Stanowi ono sedno doświadczenia mistycznego, o którym Symeon Nowy Teolog mówił, że jest percepcją łaski, dzięki której Bóg daje się poznać tym, którzy się z nim jednocza, przekraczając granice bytu stworzonego. Hezychastyczni mnisi z Góry Atos, praktykujący czystą modlitwę, twierdzili, że oglądają niestworzone światło Boga ${ }^{12}$. Palamas podkreślał, że boskie światło jest $\mathrm{w}$ istotny sposób związane $\mathrm{z}$ naturą Boga i jest rzeczywistym promieniowaniem Jego substancji. Broniąc mistycznego charakteru modlitwy mnichów atoskich, zwracał uwagę, że poprzez oczyszczenie zmysłów oraz nieustanną, czystą modlitwę osiągnęli oni łaskę widzenia tego światła, a tym samym uczestniczenia w komunii z Bogiem. To niestworzone światło to nic innego jak przebóstwiający dar Ducha Świętego. Światło to jest rozumiane jako chwała Ojca oraz jako królestwo Chrystusa - jest zatem nieskończone i niepowstrzymane ${ }^{13}$.

Dyskusja na temat hezychazmu, która wywiązała się na gruncie polemiki Grzegorza Palamasa z Barlaamem, nie mogła nie wywrzeć wpływu na sztukę tego okresu, która była niezmiernie wrażliwa na wszelkie dysputy i twierdzenia teologiczne. W jaki więc sposób doktryna hezychastyczna odcisnęła swoje piętno na sztuce i jak wpłynęła na komponowanie programów ikonograficznych? Badacze są w zasadzie zgodni co do tego, że bizantyńskie przedstawienie mandorli, z wpisanym w owal lub okrąg wielobokiem, ma związek właśnie $\mathrm{z}$ palamizmem ${ }^{14}$. $\mathrm{Z}$ drugiej strony, wprowadzenie nowych elementów symbolicznych (jak złożona mandorla, osiem promieni światła, czy też wprowadzenie trójwymiarowej tęczy), a także zmiana stylu oraz ikonografii, które pojawiły

${ }^{11}$ Por. tamże, s. 34-35.

12 Por. Y. Spiteris, Ostatni Ojcowie Kościoła, Kabasilas, Palamas, thum. B. Widła, Warszawa 2006, 229.

${ }^{13}$ Por. tamże, s. 230.

${ }^{14}$ Por. Trzcińska, Światto i obłok, s. 10-11. 
się w XIV i XV w., były wynikiem kontaktu z mistycznymi prądami duchowymi. Jednym zaś z najbardziej znaczących był bez wątpienia hezychazm ${ }^{15}$.

Szczególną uwagę wypada zwrócić na mandorlę, będącą bardzo ważnym ikonograficznym symbolem boskości. Aby w pełni zrozumieć w jaki sposób w kulturze bizantyńskiej jest przedstawiana idea objawionego Boga, należy przede wszystkim zwrócić uwagę na treści towarzyszące przedstawianiu mandorli ${ }^{16}$. Ze względu na przyjęty kształt rozróżniamy kilka typów mandorli. Najbardziej zasadniczy jest podział na mandorle o kształcie owalnym oraz mandorle okragłe. Mandorle owalne miały otaczać wyłącznie Chrystusa, natomiast mandorle okrągłe także Proroków czy Gołębicę - Ducha Świętego. Z czasem kształty mandorli zaczęły się komplikować, poprzez dodawanie innych, bardziej złożonych figur. Dzięki temu zabiegowi uzyskano mocniejszy efekt trójwymiarowości ${ }^{17}$.

Największy wpływ teologia hezychazmu wywarła na rozwój ikonografii Przemienienia (il. 6) ${ }^{18}$. Została ona również najlepiej opracowana we współczesnej literaturze przedmiotu. Mandorla uosabiająca boskie, niestworzone światło pojawia się również w scenach Anastasis oraz Koimesis.

W scenach Przemienienia pochodzących z okresu panowania dynastii Paleologów mandorle posiadają bardzo zróżnicowane kształty, a mimo to większość z nich ma jedną wspólną cechę, a mianowicie niezależnie od kształtu, często składają się one z kilku niejako nałożonych na siebie elementów. Dzięki temu zabiegowi uzyskany został efekt trójwymiarowości. Mandorla będąca symbolem niezwykłej, transcendentnej przestrzeni, stała się jednocześnie mniej jednorodna. Akcent został położony na jej elementy składowe. Przestrzeń mandorli stała się bardziej konkretna i nieco mniej eteryczna. Naturalnie zdarza się, że w scenie Przemienienia nie pojawia się w ogóle mandorla, są to jednak przypadki niezmiernie rzadkie. Można zatem przychylić się do opinii tych badaczy, którzy twierdzą, że jest ona nieomal obligatoryjnym elementem tej sceny. W tym kontekście wypada jeszcze na moment zatrzymać się przy sztuce serbskiej (il. 6 i 7), bowiem właśnie w kościołach serbskich znajdujemy mandorle o najbardziej złożonych kształtach. Stąd też pomimo tego, że są one skonstruowane na zasadzie symetrii i eurytmii, niezmiernie trudno jest określić ich kształt schematem konkretnej figury geometrycznej. Grosso modo można je definiować jako wielokąty z silnymi wcięciami. Szczególnie dobrze widoczne jest to na malowidle z monasteru w Sopoćanach (il. 6) ${ }^{19}$.

Zarówno w przedstawieniach Anastasis (il. 8 i 9) jak i Koimesis (il. 10) stykamy się z ukazaniem mistycznego światła Boga ${ }^{20}$. Zostaje ono zilustro-

\footnotetext{
${ }^{15}$ Por. Strezova, Hesychasm and Art, s. 74-75.

${ }^{16}$ Por. Trzcińska, Światto i obłok, s. 8.

${ }^{17}$ Por. tamże, s. 161-162.

${ }^{18}$ Por. Strezova, Hesychasm and Art, s. 5.

${ }^{19}$ Por. Trzcińska, Światto i obłok, s. 178-180.

${ }^{20}$ Por. Strezova, Hesychasm and Art, s. 162.
} 
wane, tak jak w przypadku sceny Przemienienia, za pomocą mandorli otaczającej postać Chrystusa. Jak już wcześniej wspomniano, w sztuce serbskiej mandorla przyjmuje skomplikowane kształty. Dodatkowo w scenie Koimesis (il. 10) znajdującej się w kościele w Gračanicy, ponad głową Chrystusa ukazane zostały otwarte drzwi niebios wypełnione liczną grupą aniołów. Zabieg ten dodatkowo podkreśla boską obecność. Z niemal analogiczną interpretacją sceny Koimesis zetkniemy się w kościele tego samego fundatora, gdzie dekoracja malarska została wykonana przez tych samych artystów, czyli przez Michała Astapasa i Eutychiosa (il. 11). Można przyjąć, że wzrost zainteresowania hezychazmem za panowania króla Milutina, związany jest, jak już wspominałam, z prowadzonym przez niego programem thumaczeń na język serbski ważnych tekstów teologicznych i filozoficznych ${ }^{21}$.

Powyższy przegląd przedstawień z terenów Królestwa Serbii, zarówno ten dotyczący przedstawień Przemienienia, Koimesis, Anastasis, jak również chrztu Chrystusa, pozwala stwierdzić, że doktryna hezychastyczna i sposoby jest obrazowania były znane i wykorzystywane przy dekoracji serbskich kościołów. Tezę tę potwierdzają również informacje o szerszym dostępie do tekstów teologicznych i filozoficznych w języku serbskim od czasów panowania króla Milutina.

\section{A FEW NOTES ON THE INFLUENCE OF HESYCHASM ON REPRESENTATION OF CHRIST'S BAPTISM ON EXAMPLE OF ART IN THE SERBIAN KINGDOM}

\section{(Summary)}

The influence of hesychasm on representation on Christ's baptism isn't so obvious as in the case of transfiguration, anastasis or koimesis. On the contrary to the mentioned above, it hasn't had its own study. We can assume, that the rise of interest in hesychasm during the kingship of Milutin is connected to Milutin's programme of translation important theological and philosophical texts into Serbian language. In all referred images, we can see a manifestation of the mystical light of God. In the case of transfigurations, koimesis and anastasis, this light is illustrated by mandorla (almond-shaped aureole) around Christ. In depictions of baptism, mandorla surround the dove of the Holy Spirit. In the Serbian art mandorla takes, repeatedly, very complicated shapes. Additionally, in the baptism and koimesis scenes, above Christ's head, appear open doors of Heaven. This can emphasise presence of God.

\footnotetext{
${ }^{21}$ Por. tamże, s. 157.
} 
Key words: Christ's baptism, Serbia, hesychasm, Anastasis, Koimesis, Transfiguration, mandorla, mystical light..

Słowa kluczowe: chrzest Chrystusa, Serbia, hezychazm, Anastasis, Koimesis, Przemienienie, mandorla, mistyczne światło.

\section{BIBLIOGRAFIA}

\section{Opracowania}

Meyendorff J., Teologia bizantyjska: historia i doktryna, thum. J. Prokopiuk, Warszawa 1984.

Spiteris Y., Ostatni Ojcowie Kościoła, Kabasilas, Palamas, tłum. B. Widła, Warszawa 2006.

Strezova A., Hesychasm and Art: The Appearance of New Iconographic Trends in Byzantine and Slavic Lands in the $14^{\text {th }}$ and $15^{\text {th }}$ Centuries, Canberra 2014.

Trzcińska I., Światto i obłok. Z badań nad bizantyńskq ikonografia Przemienienia, Kraków 1998.

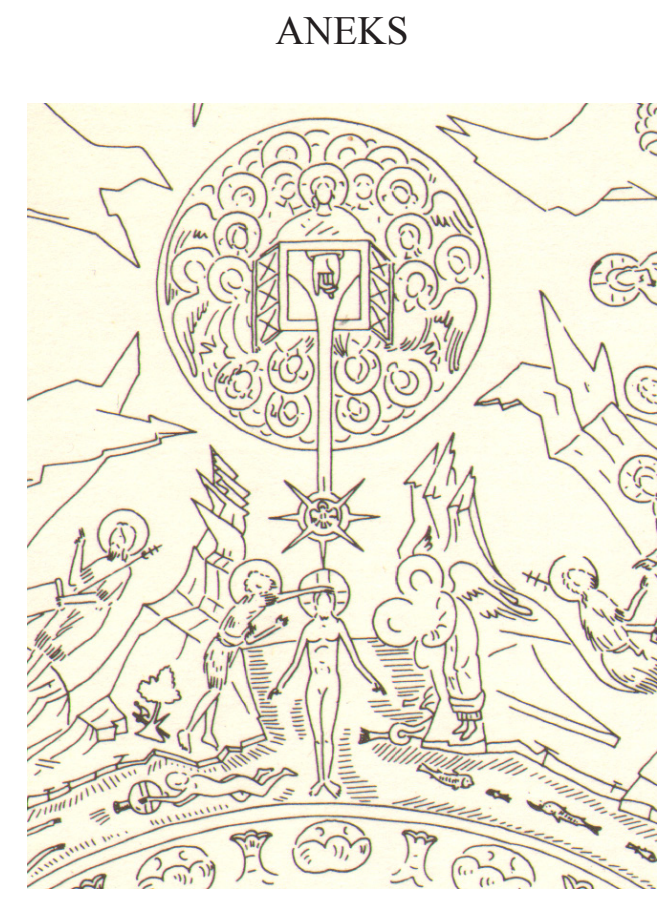

Il. 1. Bogorodica Ljeviška w Prizreniu - przedstawienie chrztu Chrystusa - skan (Д. Панић - Г. Бабић, Богородища Љевиика, Београд 1975, 140). 


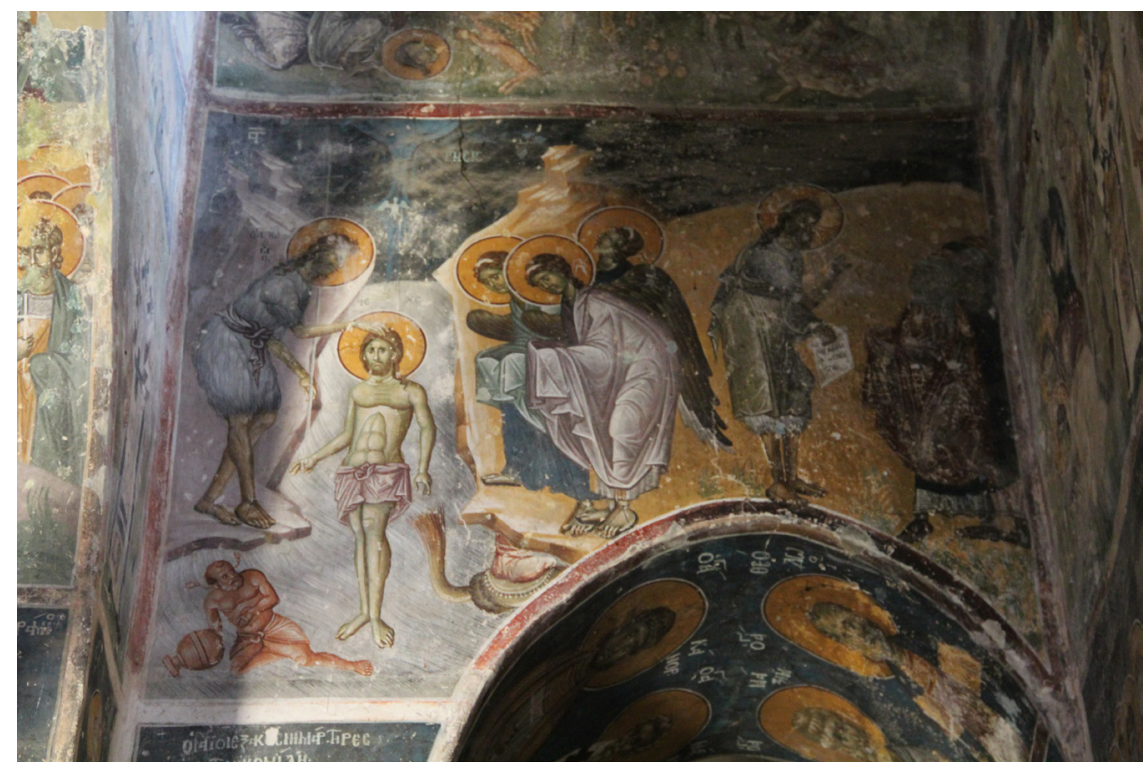

Il. 2. Staro Nagoričane - przedstawienie chrztu Chrystusa - fot. Autorki.

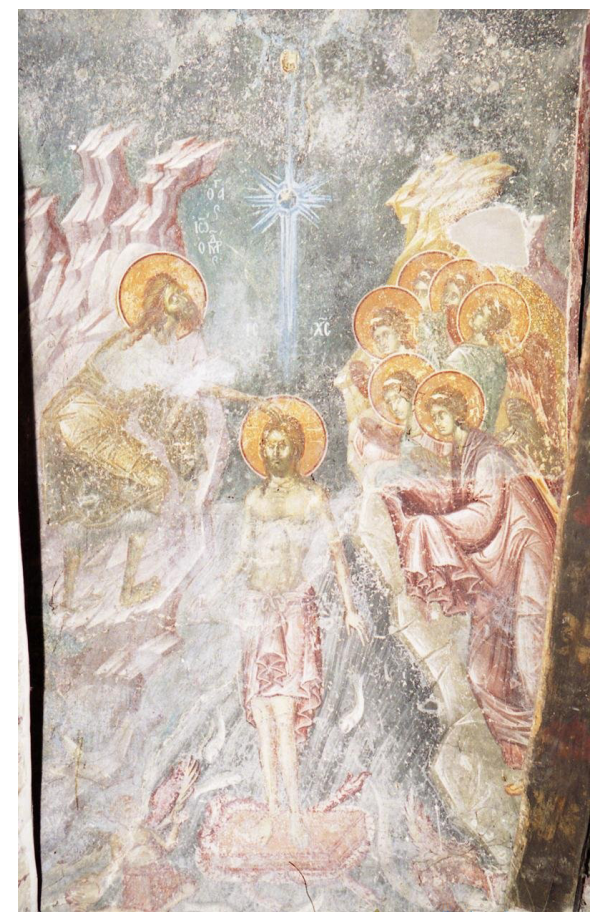

Il. 3. Čučer - przedstawienie chrztu Chrystusa - fot. dzięki uprzejmości dr hab. M. Smorąg Różyckiej 


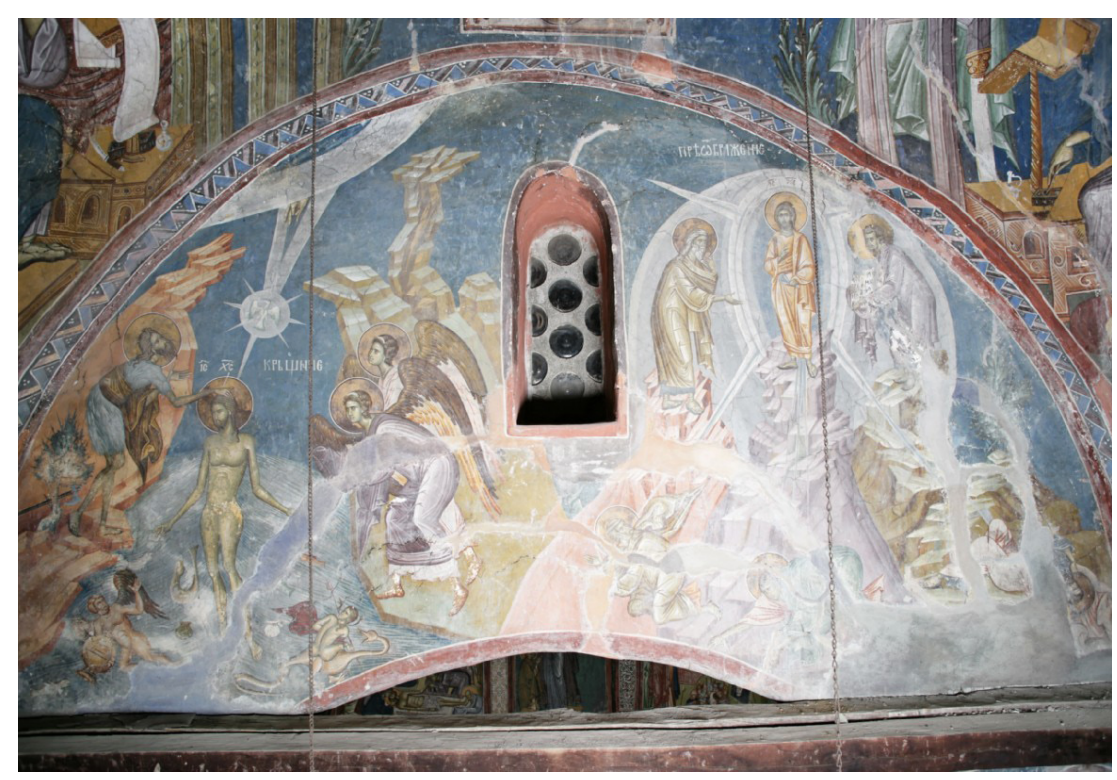

Il. 4. Monaster Patriarchalny w Peći, kościół św. Demetriusza - przedstawienie chrztu Chrystusa - fot. www.srbskoblago.org [data dostępu: 20 II 2018].

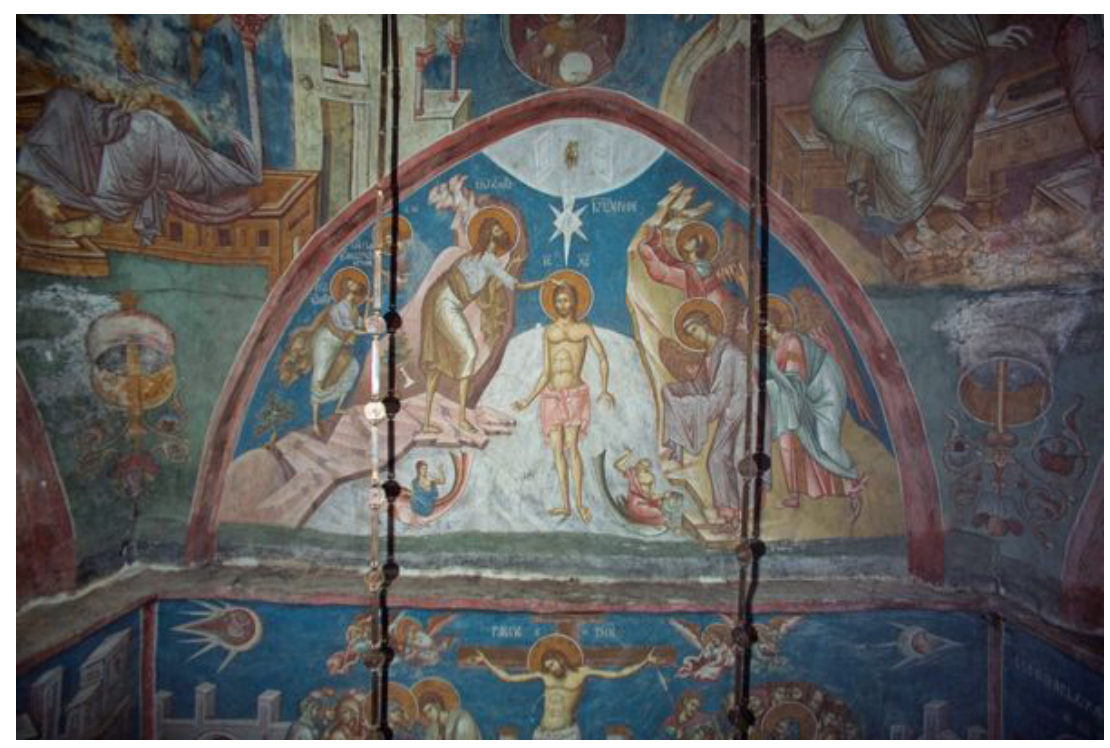

Il. 5. Monaster Dečani - przedstawienie chrztu Chrystusa - fot. www.srbskoblago.org. 


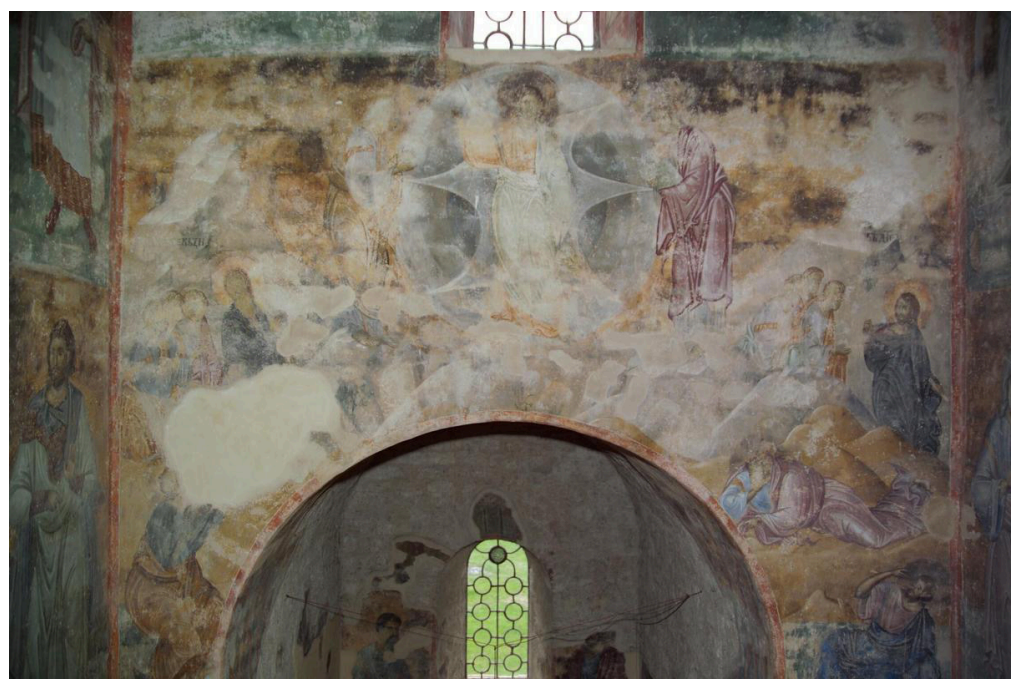

Il. 6. Monaster Sopoćani - przedstawienie Przemienienia - fot. www.srbskoblago.org.

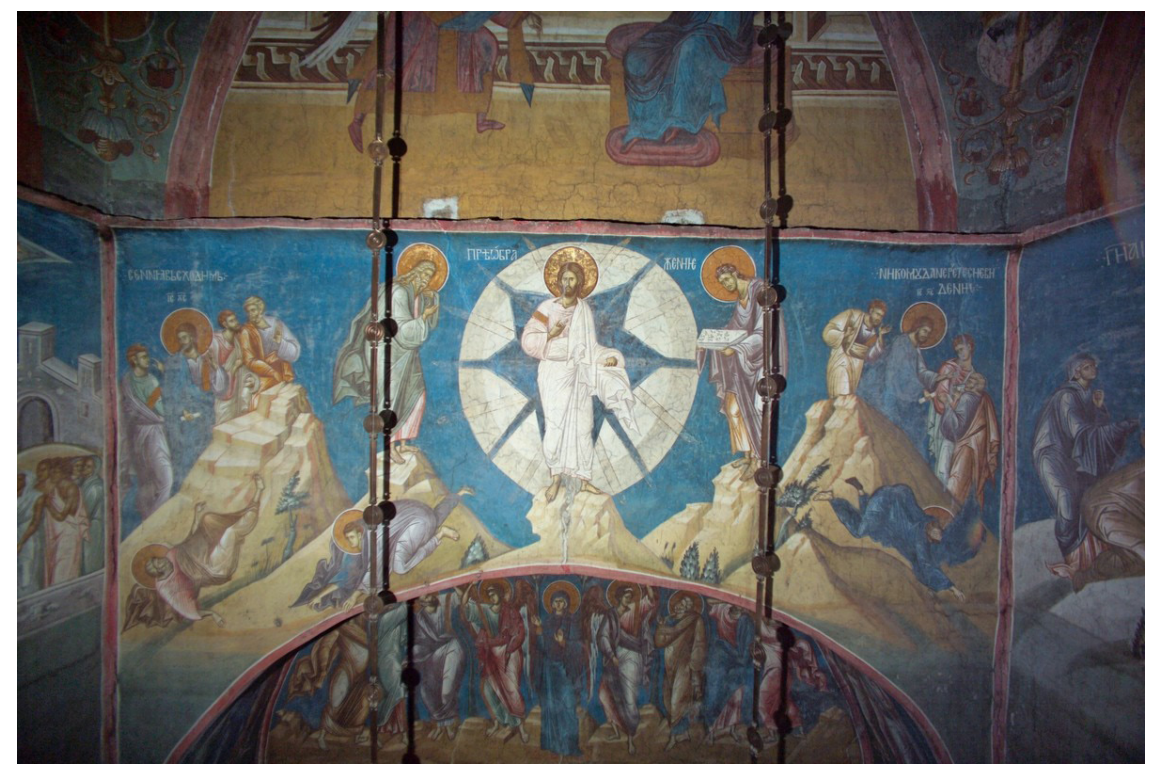

Il. 7. Monaster Dečani - przedstawienie Przemienienia - fot. www.srbskoblago.org 


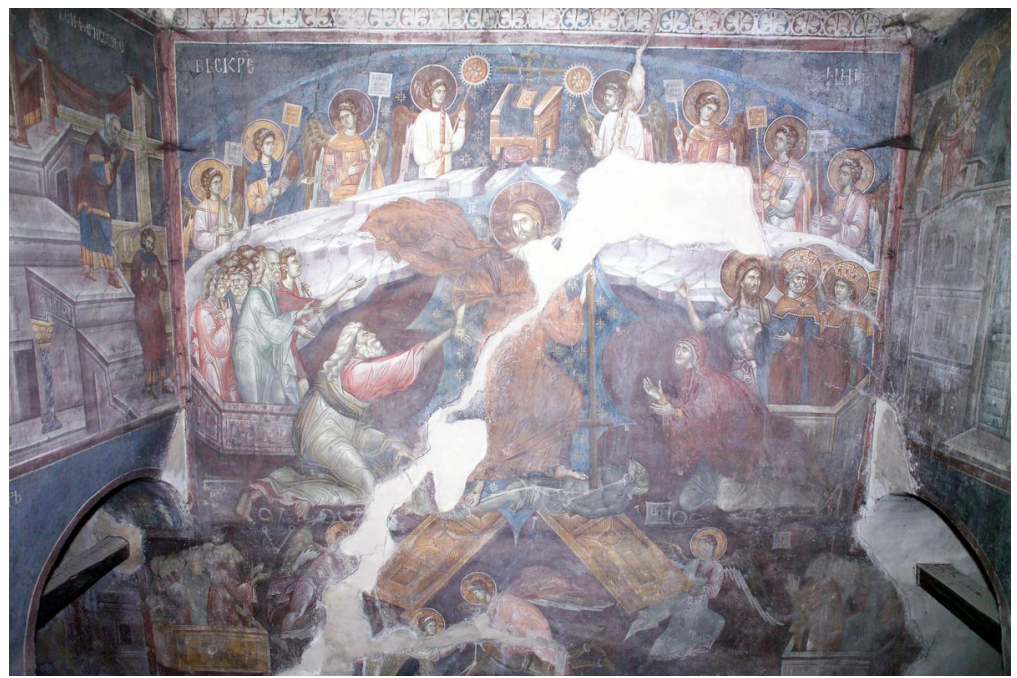

Il. 8. Monaster Gračanica - przedstawienie Anastasis - fot. www.srbskoblago.org.

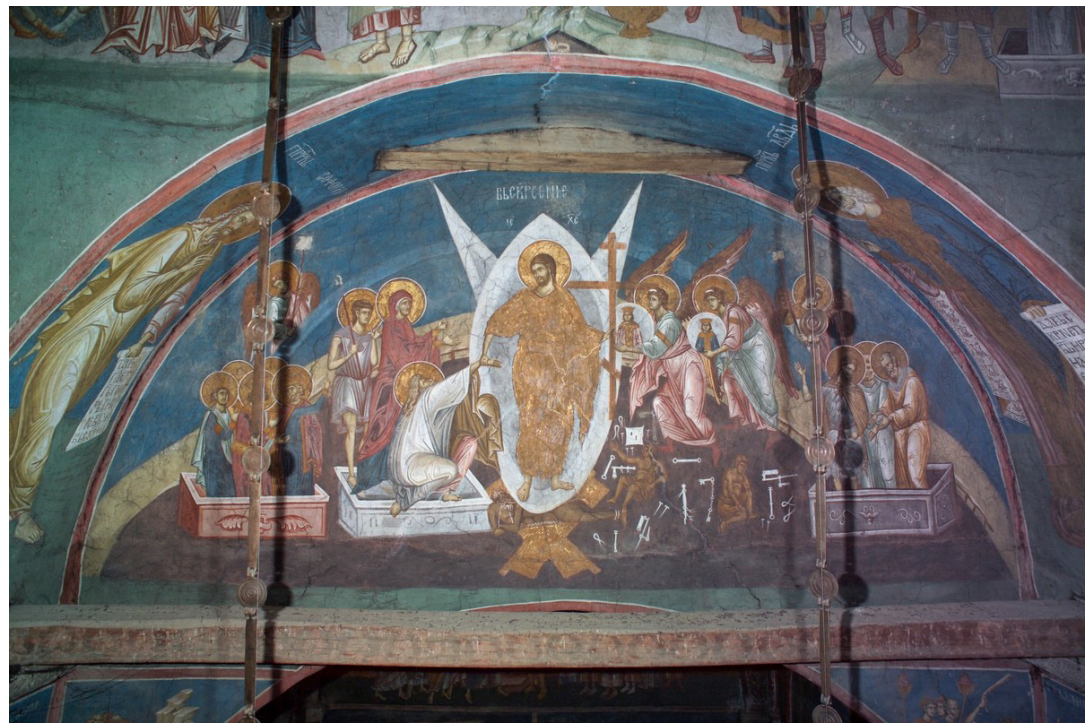

Il. 9. Monaster Dečani - przedstawienie Anastasis - fot. www.srbskoblago.org. 


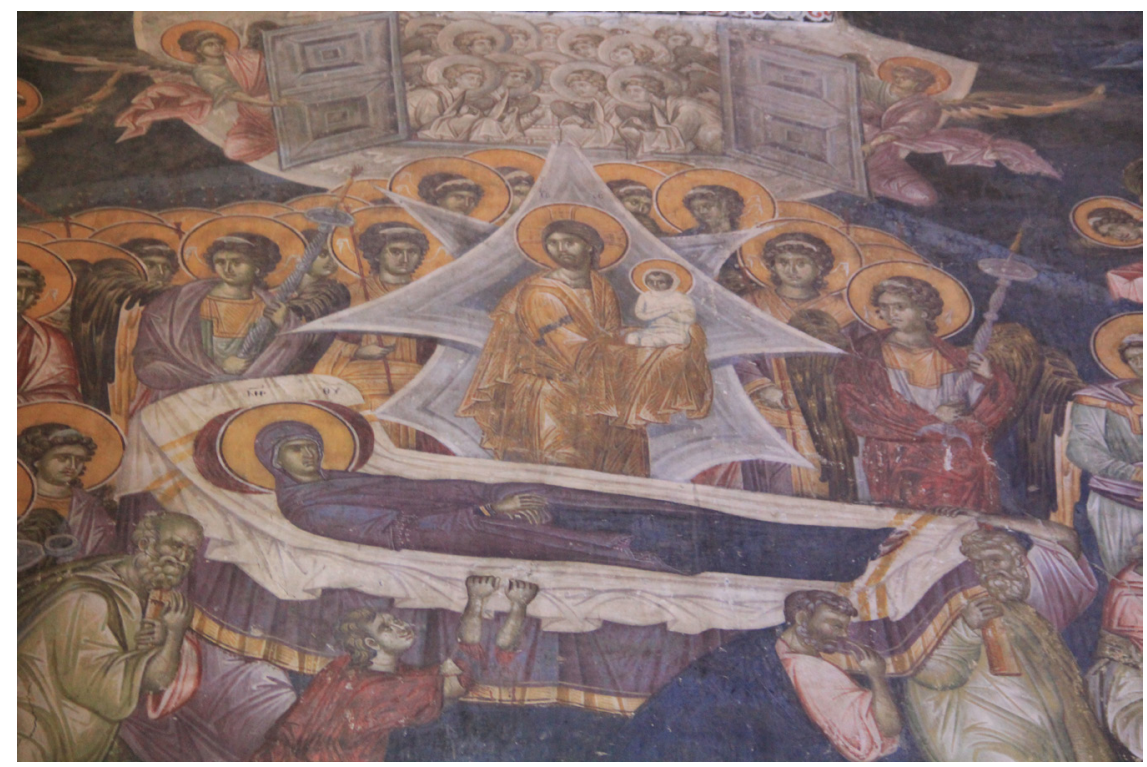

Il. 10. Monaster Gračanica - przedstawienie Anastasis - fot. Autorki.

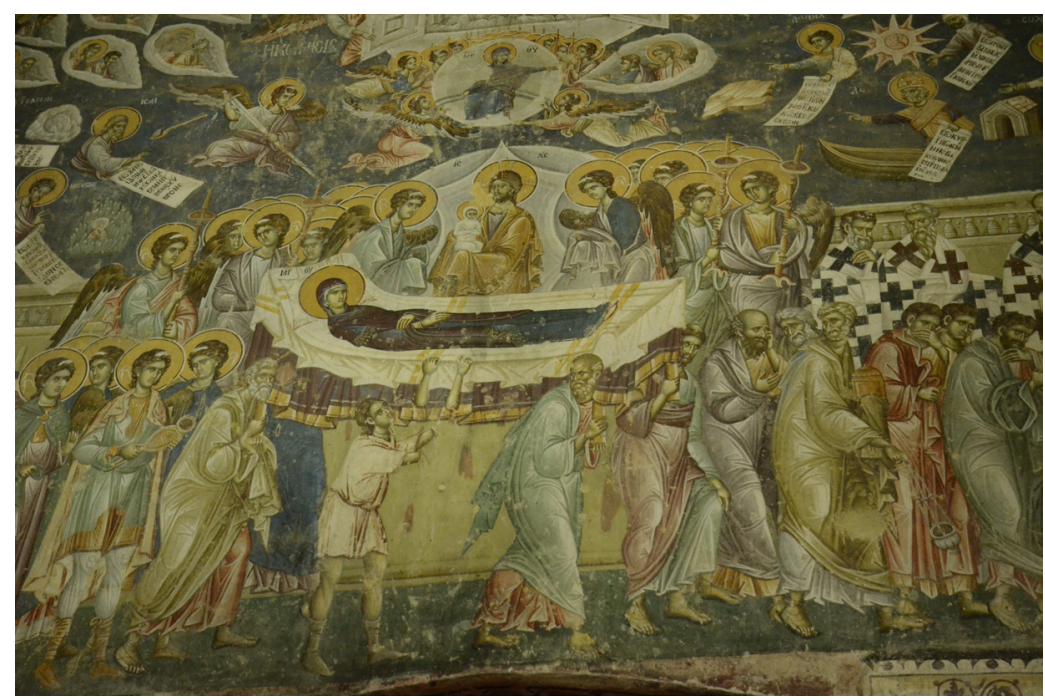

Il. 11. Staro Nagoričane - przedstawienie Koimesis - fot. www.upload.wikimedia.org [data dostępu: 20 II 2018]. 
